\title{
The treatment of post-burn breast scars
}

\section{Tratamentul cicatricilor postcombustionale de la nivelul sânului}

\author{
Cătălin BEJINARIU, Ioana APOSTOLESCU, Silviu MARINESCU
}

Secţia de Chirurgie Plastică şi Microchirurgie Reconstructivă, Spitalul Clinic de Urgenţă „Bagdasar-Arseni“, Bucureşti, România

\begin{abstract}
This paper presents the case of a 36-year-old patient who has been the victim of a deflagration when she was 8 years old, suffering from IIb-III degree burns affecting the upper limbs, thorax and abdominal region. Following clinical evaluation, the therapeutic protocol was developed to address functional and aesthetic considerations. Recovering the right upper leg mobility, discontinuing the retraction of the scar, involving the brachial, axillary and mammary regions, as well as creating local premises in order to facilitate breast tissue expansion before breast reconstruction were the main objectives of reconstructive treatment. The evolution of the burn scars from her childhood requires staged surgical interventions while aiming to create optimal conditions for the development of the affected anatomical structures.
\end{abstract}

Keywords: burn scars, post-burn breast scars, breast reconstruction

\begin{abstract}
REZUMAT
Lucrarea de față prezintă cazul unei paciente în varstă de 36 de ani care a fost victima unei deflagrații la 8 ani, traumatismul soldându-se cu arsuri de gradul IIb - III la nivelul membrelor superioare, toracelui şi regiunii abdominale. In urma evaluării clinice protocolul terapeutic a fost elaborat pentru rezolvarea considerentelor de tip funcțional şi estetic. Recuperarea mobilității membrului superior drept, întreruperea continuității cicatricei retractile implicând regiunile brahială, axilară şi mamară, precum şi crearea premiselor locale pentru facilitarea expandării mamare în vederea reconstrucției sânului au reprezentat principalele obiective ale tratamentului reconstructiv. Evoluția cicatricilor postcombustionale survenite în copilărie, reclama efectuarea unor intervenții chirurgicale etapizate, pentru crearea condițiilor optime de dezvoltare a structurilor anatomice afectate.
\end{abstract}

Cuvinte cheie: cicatrice postcombustională, arsura sânului, reconstrucție de sân

\section{INTRODUCERE}

Reconstrucţia sânului reprezintă un subiect de actualitate, literatura ştiinţifică de specialitate dedicată acestui subiect abundă de informaţie de calitate cu privire la procedurile utilizate, protocolul adecvat, precum şi conduita postoperatorie recomandată. Obţinerea unor rezulta- te bune şi de durată se bazează pe o planificare preoperatorie riguroasă, ce trebuie să ţină cont de particularităţile locale, contextul clinic în care se desfăşoară procedura şi aşteptările pacientei cu privire la prognostic (1). Fără doar şi poate reconstrucţia sânului este mult îngreunată în cazul pacientelor care prezintă cicatrici postcombustionale, care prin topografia locală 
interesează liniile de forţă, exercitând efecte de tracţionare asupra complexului areolă-mamelon, precum şi a glandei mamare în întregime (2).

Opţiunile reconstructive clasice care presupun expandare tisulară urmată de inserarea protezelor siliconice sau plastiile cu lambouri miocutanate, asociate sau nu cu implanturi mamare, sunt practic sortite eşecului dacă în prealabil nu se rezolvă problema cicatricilor tegumentare retractile, care pe de o parte ancorează tegumentul la planurile profunde, iar pe de altă parte limitează mişcările regiunii axilare şi a braţului în consecinţă (3).

Reperele anatomice ale glandei mamare, raportul pe care aceasta îl are cu toracele şi sinergia motorie cu regiunea axilară şi braţul, sunt toate elemente ce trebuie luate în considerare în momentul elaborării planului operator. Linia mediană anterioară, linia medioclaviculară şi nu în ultimul rând linia axilară anterioară sunt principalele repere topografice locale, având o importanţă semnificativă în ceea ce priveşte realizarea protocolului reconstructiv (4). Prezenţa sechelelor cicatriceale la nivelul toracelui anterior îngreunează cu mult realizarea intervenţiei chirurgicale reconstructive, opţiunile terapeutice fiind practic mult limitate de aceste neajunsuri.

Istoricul personal patologic al pacientei este esenţial pentru elaborarea protocolului reconstructiv, localizarea cicatricei postcombustionale, proprietăţile acesteia şi durata scursă de la traumatism sunt elemente cheie, ce trebuie integrate în algoritmul terapeutic (5).

\section{PREZENTARE DE CAZ}

Autorii prezintă în lucrarea de faţă cazul unei paciente în vârstă de 36 de ani, care a fost victima unei deflagraţii în copilărie. În urma traumatismului care a avut loc la vârsta de 8 ani pacienta a suferit o arsură grad IIb - III la nivelul hemitoracelui anterior drept cu interesarea regiunii axilare şi a flancului. Pacienta a suferit multiple intervenţii chirurgicale constând în plastie cu piele liberă despicată, precum şi „Z“ plastii seriate în intervalul scurs de la traumatism până la prezentarea în clinica noastră, rezultatul acestora fiind influenţat negativ de procesul de creştere (Fig. 1).

În momentul evaluării pacienta prezenta o cicatrice postcombustională extinsă la nivelul regiuni mamare drepte cu hipoplazie unilaterală, precum şi o cicatrice retractilă la nivelul liniei axilare anterioare ce ancora glanda mamară la axilă, limitând astfel mobilizarea braţului drept. Corespunzător proiecţiei liniei axilare anterioare, cicatricea se extindea inferior de sanţul inframamar până la nivelul flancului drept.

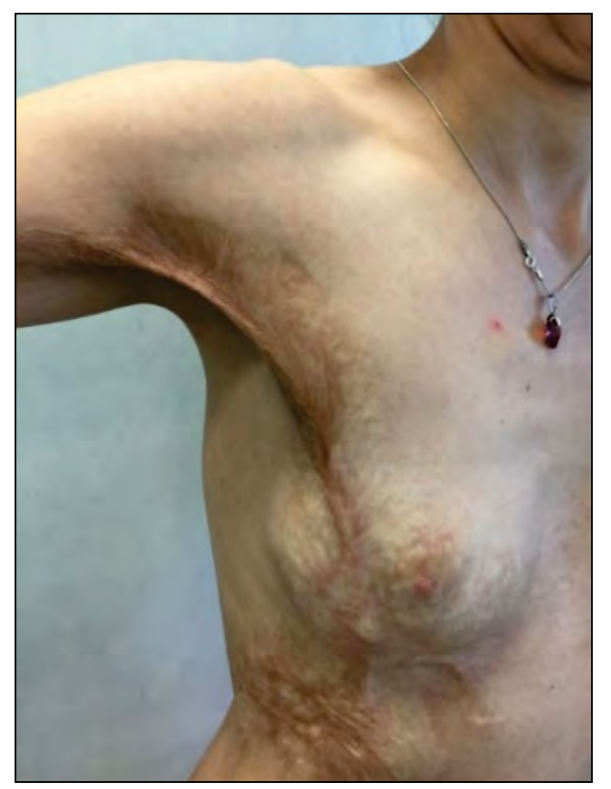

FIGURA 1. Aspect preoperator-Placard cicatriceal

La palpare se evidenţia consistenţa crescută a placardului cicatriceal şi aderenţa acestuia la glanda mamară subjacentă şi la fascia pectorală, precum şi prelungirea bridei cicatriceale la nivelul liniei axilare anterioare şi continuarea acesteia la nivelul feţei antero-mediale a treimii superioare a braţului.

La mobilizare se vizualiza ascensionarea accentuată a sânului drept în timpul mişcării de abducţie a braţului, precum şi limitarea mişcării membrului toracic drept, valoarea maximă a unghiului de abducţie fiind de 90 de grade. Impotenţa funcţională generată de limitarea mişcării de ridicare a braţului peste nivelul umărului a fost considerată ca fiind inacceptabilă de către pacientă, acesta fiind unul dintre motivele prezentării la spital.

În urma examinării clinice s-a decis elaborarea unui protocol care sa cuprinda trei obiective principale:

- redobândirea funcţionalităţii membrului toracic drept;

- alungirea cicatricei de la nivelul sânului drept;

- întreruperea continuităţii cicatricei longitudinale de la nivelul liniei axilare anterioare.

Pentru recuperarea funcţionalităţii membrului toracic drept prin eliberarea tensiunii de la nivelul regiunii axilare, $\mathrm{s}$-a optat pentru plastie prin „jumping man flap“ (Fig. 2), alungirea cica- 
tricei retractile de la nivelul peretelui anterior al axilei reprezentând soluţia optimă pentru rezolvarea acestui deziderat.

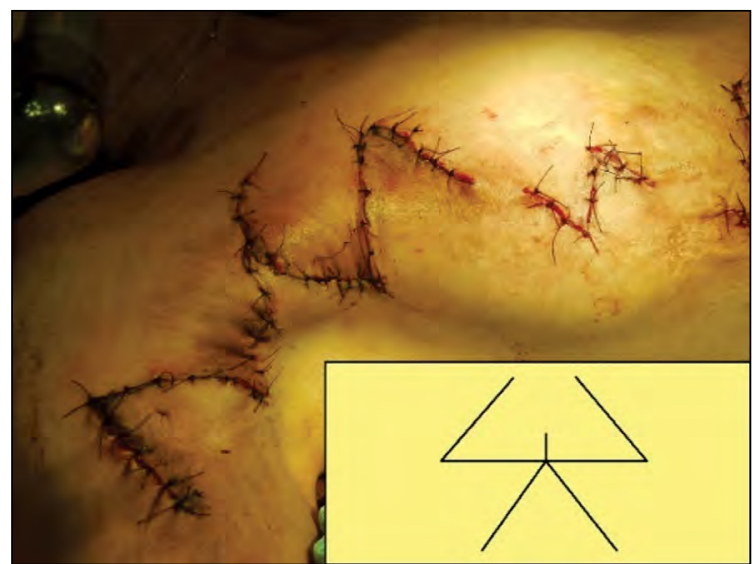

FIGURA 2. Aspect intraoperator-Alungirea cicatricei retractile prin „Jumping man flap“

Pentru asigurarea „fundaţiei“ reconstrucţiei mamare ulterioare $s-a$ optat pentru realizarea unei „Z" plastii la nivelul placardului cicatriceal care deforma regiunea mamară dreaptă, astfel încât prin alungirea cicatricelor de la acest nivel să se creeze condiţiile necesare unei expandări tisulare ulterioare.

Pentru redobândirea unui aspect cât mai natural al hemitoracelui drept un prim pas a fost reprezentat de întreruperea cicatricei retractile suprapuse pe linia axilară anterioară, brida cicatriceală ce consolida într-un bloc cicatriceal trei regiuni anatomice învecinate: braţul în treimea lui superioară, axila şi sânul.

Prin realizarea plastiei cu lambou în „,W“ s-a obţinut alungirea cicatricei din regiunea axilară şi totodată întreruperea bridei retractile ce unea cele trei regiuni anatomice anterior menţionate.

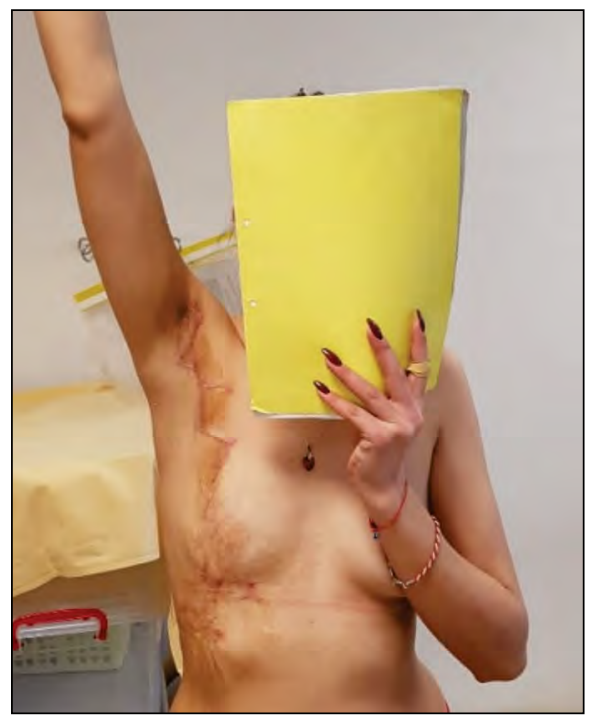

FIGURA 3. Rezultat postoperator (30 de zile)
În urma efectuării intervenţiei chirurgicale reconstructive pacienta şi-a redobândit în totalitate gradul de mobilitate al articulaţiei glenohumerale, unghiul de abducţie crescând de la valoarea de 90 de grade la 165 de grade (Fig. 3).

În ceea ce priveşte aspectul sânului, s-a remarcat o îmbunătăţire semnificativă a formei, însă aspectul cel mai important şi cel care a ghidat efectuarea intervenţiei este cel al creării condiţiilor necesare expandării tisulare în vederea corectării deficitului volumetric.

\section{DISCUȚII}

Durata de timp dintre traumatism şi momentul prezentării la spital este extrem de importantă, implicaţiile acesteia exercitându-şi efectele pe mai multe planuri. In ceea ce priveşte dezvoltarea naturală şi armonioasă a glandei mamare, traumatismele produse prin combustie în copilărie, au tendinţa să limiteze dezvoltarea acesteia, rezultatul nefast al acestui proces fiziopatologic fiind reprezentat de obţinerea unor asimetrii care pot fi greu tolerate de paciente (6). O altă problemă este cea a dezvoltării cicatricilor retractile (limitante), care odată cu trecerea timpului au tendinţa să fixeze glanda mamară la structurile învecinate, linia axilară anterioară fiind în acest sens principalul reper anatomic implicat. Cicatricile retractile localizate la acest nivel au tendinţa de a limita mişcarea braţului prin ancorarea regiunii axilare şi mamare (7).

Reconstrucţia sânului în cazul pacientelor cu cicatrici postcombustionale trebuie sa aibă ca fundaţie rezolvarea cicatricilor retractile care îşi exercită efectele la nivel funcţional, urmând ca ulterior, după rezolvarea acestei probleme să fie adresate aspectele volumetrice şi de simetrie, elemente extrem de importante pentru obţinerea unor bune rezultate postoperator (8).

Tratamentul cicatricilor retractile constă adesea în plastii cu lambouri tegumentare locale, loco-regionale, sau în formele severe chiar lambouri liber transferate. Frecvent pentru rezolvarea deficitelor funcţionale survenite din cauza cicatricilor retractile sunt utilizate,$Z^{\prime \prime}$ plastiile (9), sau variaţii mai complexe ale acestora cum este cazul lamboului în „,W“ sau ,jumping man flap", aşa cum este cunoscut în literatura de specialitate. Prin disecţia acestor lambouri conform unor unghiuri stabilite preoperator se pot obţine grade variate de alungire a zonelor cicatriceale astfel încat să reducem sau chiar să anulăm efectele nefaste ale vindecării patologice. 


\section{CONCLUZII}

Fără doar şi poate problematica reconstrucţiei de sân este una complexă care implică o multitudine de factori ce ţin de particularităţile anatomice locale, protocolul terapeutic urmat de pacientă şi aşteptările acesteia cu privire la rezultatul postoperator, cu toate acestea respectarea elementelor chirurgicale de bază şi a principiului construcţiei sănătoase (etapă după etapă) reprezintă în opinia autorilor cheia de boltă pentru rezolvarea acestor cazuri.

Conflict of interest: none declared Financial support: none declared

\section{BIBLIOGRAFIE}

1. Enescu DM, Bordianu I, Manual de Chirurgie Plastica, Ovidius Univ Pres, 2001.

2. El-Otiefy MAE, Darwish AMA, Post-burn breast deformity: various corrective techniques, Ann Burns Fire Disasters. 2011: 24(1): 42-45.

3. Balumuka DD, Galiwango GW, Alenyo R. Recurrence of post burn contractures of the elbow and shoulder joints: experience from a Ugandan hospital, BMC Surgery, 2015:15:103.
4. Özgenel G, Akın S, Kahveci R, Turan Ş, Özcan M, Reconstruction of burn-damaged female breasts, European Journal of Plastic Surgery 2002: Volume 25: Issue 3:152-155.

5. Herndon DN, Total Burn Care $5^{\text {th }}$ edition, 2018.

6. Enescu DM, Arsurile, Chirurgie plastica si microchirurgie reconstructivă, Editura Academiei Romane, volumul 6.

7. Karki D, Mehta N, Narayan RP. Post-burn axillary contracture: A therapeutic challenge, Indian J, Plast Surg. 2014: 47(3): 375-380.

8. Nisanci M, Sahin I, Guzey S. An Extraordinary Case of Axillary Contracture: Trapped Healthy Skin and Its Adnexes Under Contracted Scar, Int Surg. 2014: 99(4): 442-446.

9. Matsumoto EA, Liang $H$, Mahadevan L. Topology, Geometry, and Mechanics of Z Plasty, 2018: vol. 120: Issue 6-9. 